\title{
Traditional Games on Character Building: Integrating Hide and Seek on Learning
}

\author{
Asrial1, Syahrial², Dwi Agus Kurniawan3, Muhammad Dewa Zulkhi4 \\ DOI: $10.35445 /$ alishlah.v13i3.813
}

\begin{tabular}{l} 
Article Info \\
\hline \\
Keywords: \\
Character; \\
Hide and Seek; \\
Response; \\
Traditional Game
\end{tabular}

Keywords:

Karakter;

Permainan Tradisional; Hide and seek;

Respon

\section{Abstract}

The purpose of this study was to determine the effect on learning of incorporating the traditional game of Hide and Seek. This type of research employs a mixed-methods. This study used several variables as research categories, including response, peace-loving character, and patriotism, and enrolled a total of 44 students. Descriptive and inferential statistics were used in the data analysis. The integration took place at an Elementary School and a Madrasah Ibtidaiyah in Batang Hari, as evidenced by the response, which reflected the peace-loving nature of patriotism. The result is that each response variable, peace, love, and patriotism, has a significant effect, with a value of sig 0.05, and that each variable is dominant in the good category.

\section{Abstrak}

Tujuan penelitian ini adalah untuk melihat pengaruh pengintegrasian permainan tradisional Hide and seek pada pembelajaran. Jenis penelitian ini adalah mix method. Penelitian ini melibatkan beberapa variabel sebagai kategori penelitian yaitu respon, karakter cinta damai dan karakter cinta tanah air dengan jumlah sampel 44 siswa. Analisis data menggunakan statistik deskriptif dan inferensial. Pengintegrasian dilakukan di Sekolah Dasar Negeri dan Madrasah Ibtidaiyah Batang Hari dilihat pada respon, karakter cinta Damai dan karakter cinta tanah air. Hasilnya setiap variabel dari respon, karakter cinta damai dan karakter cinta tanah air memiliki pengaruh yang signifikan, dengan nilai sig<0,05 dan pada setiap varibel dominan dalam kategori baik.

\footnotetext{
${ }^{1}$ Universitas Jambi, Indonesia Email : porigih@gmail.com

${ }^{2}$ Universitas Jambi, Indonesia Email : syahrial.karea@gmail.com

${ }^{3}$ Universitas Jambi, Indonesia Email : dwiagus.k@unja.ac.id

${ }^{4}$ Universitas Jambi, Indonesia Email : dewasarolagun@gmail.com Vol.13 (3) December, 2021

Received: July 16, 2021; Received in revised form: September 23, 2021; Accepted: September 27, 2021; Available online: December 31, 2021. This is an open access article under a Creative Commons Attribution-NonCommercial-ShareAlike 4.0 International License.
} 


\section{INTRODUCTION}

Character education is critical for the nation, as a good character contributes to the creation of a good country. Character education refers to the act of forming character in students (Damon, 2013; Nucci \& Narváez, 2014; Ramdhani, 2017). Character education is more important than knowledge because what is intelligent but lacks a positive personality, which is why character education is so critical (Omeri, 2015; Sahroni, 2017; Munawwaroh, 2019). As a result, character education is incorporated into all aspects of learning. (Wiliandani, Wiyono, \& Sobri, 2016; Julyha, 2014). Learning is the interaction between teachers and students in a learning environment. Learning is an aid provided by teachers to add knowledge, skills, and attitudes (Afandi, 2013; Suardi, 2018; Muhali, 2019). Good learning will then produce qualified students (Lehtinen, Hakkarainen \& Palonen, 2014; Fathurrohman, 2015). One of them is fun learning by playing (Rohmawati, 2015; Miskawati, 2019; Risalah, Zahro \&Aisyah, 2021), which integrates traditional games as fun learning in character shaping.

Traditional games are all forms of playing activities owned by each region with certain characteristics (Kurniati, 2016: Widodo \& Lumintuarso, 2017: Hanief, 2017). Traditional games in Indonesia are so many because Indonesia has a lot of tribes and ethnicities. Therefore it is not surprising that traditional games in Indonesia are very diverse (Nursyahidah \& Putri, 2013; Ridwan, 2016; Abda'u, Hanurawan \& Sutarno, 2020). In harmony with (Furio 2013; Lum, et al., 2018; Selasih \& Sudarsana, 2018), the value of traditional games are implemented in learning because it has a source of cultural-based lessons and also character values to establish a strong and characterful nation. In addition to taking character values also to add insight into the culture around and to always maintain and preserve the existing culture so as not to be lost.

Research on the benefit of the traditional game has conducted by several researchers. (Paulsen, 2013; Mas'udah, 2015; Watts, 2018) explain the game of hide and seek is a game that is done with friends and looking for friends who are hiding. Hide and seek is a traditional game that many children play in Indonesia because it is fun and easy to play. (Setiawan, 2016; Purnamasari, Sartinah, 2019) Hide and seek also has several benefits, including training students' memories, developing students' abilities in the cognitive field, training gross motor in students, and developing social skills in students, with many benefits and values contained in traditional games of hide and seek so it is very good when combined in learning, especially forming the character of peace love and love of the homeland, (Sari, Saparahayuningsih, \& Wembrayarli, 2020; Ashar, \& Inrawulan, 2021).

A peace-loving character is an attitude in which a person feels happy, maintains the surrounding environment and does not damage or cause division. Hidayati, Dkk, 2014; Ayu Anggraeni, 2016; Syaefudin, \& Santoso, 2018), the character of peace-loving students must be instilled early so that the school environment is always peaceful, away from violence and damage in the surrounding environment. (Princess, \& Safitri, 2018; Dwi, 2019 is not only in the school environment but also in all neighbourhoods, both family and general environments. Every Indonesian must have a strong love of the country in them. (Suarta, 2017; Maarif \& Rofiq 2018; Talapessy, Kumalasari \& Salouw 2020). The character of patriotism is needed for students as the next generation of the nation who are proud to be Indonesian society with various cultures at their disposal. With the strong character of the love of the homeland, any interference from outside cultures entering Indonesia will not affect the people of Indonesia Widiatmaka, 2016; Rifa'i, Prajanti, \& Alimi, 2017). 
This research is to find out the influence of the integration of traditional games in public elementary schools and state madrassas to the response, the character of Peace Love and the character of the love of the homeland. In contrast, many previous studies have examined many about the influence on the integration of traditional games. This study aims to find out the influence of peace-loving characters and patriotism characters in elementary schools by using the traditional game Hide and seek.

\section{METHOD}

This research uses quantitative and qualitative approaches (Mixed Method) is if the researcher has questions that need to be tested in terms of the type of research and process and concerns the combination of quantitative and qualitative methods in one study (Senjaya, 2018; Hermawan, 2019;). Using explanatory sequential design research design implies collection and quantitative analysis as the main data and then qualitative data in two consecutive phases in one study (2013; Li et al., 2015; Wipulanusat et al., 2020).

Research instruments use questionnaires and interviews. QuestionnaireQuestionnaire is a data collection tool that can be done by disseminating a series of questions and written statements to sources from research sample members (Maryuliana, Subroto \& Haviana, 2016; Sudibyo, Jatmiko \& Widodo, 2017; Gunawan et al., 2019). The questionnaire is used in the form of questionnaires patriotism and peace love and response to the application of traditional game of hide and seek. With the number of valid questions every 16 questions. Reliability is calculated using the Cronbach alpha formula. After the instrument was tested and analyzed reliability, the reliability coefficient of the homeland love questionnaire of 0.760 and for peace-loving characters 0.730 and response questionnaires of 0.740 so that it can be concluded that the instrument is reliable. The questionnaire uses the Likert scale category with the type of scale strongly agreed (SS), agree (S), unsure (N), disagree (TS), and strongly disagree (STS). In any positive problem in an instrument that has a value: $\mathrm{SS}=5, \mathrm{~S}=4, \mathrm{~N}=3, \mathrm{TS}=2$, and $\mathrm{STS}=1$. The score is reversed for the value on the negative problem item. Questionnaires given to respondents are used to measure quantitative data. Here's the research grid:

Table 1. Student's response to peace-loving questionnaire

\begin{tabular}{llll}
\hline No. & Assessment Aspects & Statement & $\begin{array}{l}\text { Number } \\
\text { Items }\end{array}$ \\
\hline $\mathbf{1}$ & Forgive each other & Apologize if it's wrong & 4 \\
$\mathbf{2}$ & Take care of the environment & Not damaging things around & 4 \\
3 & Behave politely & Speaking a smooth word & 4 \\
4 & Not bothering others & No fooling friends & 4
\end{tabular}

Below is a table of gratings for the character of the love of the student's homeland with the traditional game Hide and seek application. The lattice of the character of love of the homeland is used as a guideline for preparing the problem in the research questionnaire. 
Table 2. Students' patriotism questionnaire

\begin{tabular}{lllll}
\hline No. & Assessment Aspects & Statement & $\begin{array}{l}\text { Number } \\
\text { Items }\end{array}$ & of \\
\hline $\mathbf{1}$ & $\begin{array}{l}\text { Bringing the name of the } \\
\text { nation to the }\end{array}$ & Learn to reach the mind & 4 \\
2 & $\begin{array}{l}\text { Respect each other } \\
3\end{array}$ & $\begin{array}{l}\text { Maintaining the good } \\
\text { name of the nation }\end{array}$ & $\begin{array}{l}\text { Appreciate the difference } \\
\text { Not misbehaving }\end{array}$ & 4 \\
4 & Working together & $\begin{array}{l}\text { Helping a friend in distress } \\
\text { Helping someone who needs help }\end{array}$ & 4 \\
\hline Sum & & & 4 \\
\hline
\end{tabular}

The interview is a technique of collecting data in the form of information from a source by asking questions and statements(Arismunandar, 2013; Rosaliza, 2015; Siregar, 2016). The interview used is a short question, with a number of questions each 18. As for the interview grid as follows:

Table 3. Teacher Interview Grid

\begin{tabular}{llll}
\hline \hline No. & Assessment aspect & Statement & $\begin{array}{l}\text { Number of } \\
\text { questions }\end{array}$ \\
\hline 1 & $\begin{array}{l}\text { Traditional Games } \\
\text { The student's peace- }\end{array}$ & $\begin{array}{l}\text { Games that have been played in school } \\
\text { Frequent fights between students? }\end{array}$ & 6 \\
3 & $\begin{array}{l}\text { loving character } \\
\text { of the homeland }\end{array}$ & Bringing up the good name of the school & 6 \\
\hline Sum & & 18 \\
\hline \hline
\end{tabular}

Interviews are also conducted with students to find out the response of learners to the application of traditional games of Hide and seek. With the interview grid as follows:

Table 4. Student Interview Grid

\begin{tabular}{llll}
\hline \hline No. & Assessment aspect & Statement & $\begin{array}{l}\text { Number of } \\
\text { questions }\end{array}$ \\
\hline 1 & Hide and seekgame & Have you ever played with friends? & 4 \\
2 & Student response & Feelings when playing Hide and seek & 4 \\
3 & Peace-loving character & Respecting differences between religions, tribes & 4 \\
4 & The character of the love & Proud to be a child of Indonesia & 4 \\
\hline of the homeland & & & 18 \\
\hline \hline
\end{tabular}

The population in this study is the number of all students of grade IV in Sridadi State Elementary Batang Hari. The sample used is all students of grade IV elementary school N 55 / I Sridadi and Class IV MIN 1 Batang Hari, which amounted to 44 students. In the determination of samples used sampling techniques, namely purposive sampling, the sampling technique is done with certain considerations (Etikan, Musa, \& Alkassim, 2016; Sugiono, 2019) where the criteria applied by researchers are considerations of the state of the school and learners, the school is examined by researchers using printed and electronic teaching materials, where this facilitates the data obtained by researchers in seeing the character of Peace Love with the integration of traditional games of Hide and seek. 
The data collection technique used is quantitative data collection as the main data and is reinforced with qualitative data. Quantitative data involves numbers or numbers (Rofiah, Aminah \& Ekawati, 2013; Diamonds, 2018; Zein et al., 2019). Quantitative data is a type of data that can be measured or calculated directly. Existing quantitative data is reinforced by qualitative data generated from interview results. Qualitative data is data from verbal word explanations that cannot be analyzed in the form of numbers or numbers(Gunawan, 2013; Hasanah, 2017; Rijali, 2019). In research, qualitative data is in the form of an overview of the research object. Qualitative data provides and shows the quality of the research objects carried out.

The data analysis in this study used descriptive statistics and inferential statistics. Descriptive statistical information is used to analyze data by describing or describing the data collected without drawing general applicable conclusions or generalizations (Junaidi, 2014; Sari \& Wardani, 2015; Sugiono, 2019). The study used descriptive statistics using maximum, minimum, mean and standard deviation values. In contrast, inferential statistics is a statistical calculation used to analyze data from a sample. The results will be generalized or concluded for the sample population it was taken (Widiana, 2016; Sutopo \& Slamet, 2017). By using the assumption test, namely the test of normality and linearity by taking the results of sig value decisions on the processed data. As well as using the hypothesis test is a regression test with the provision that if the sig value < probability of 0.005 , then there is the influence of one free variable $(\mathrm{X})$ or more on the bound variable $(\mathrm{Y})$ or the hypothesis is accepted. If the sig value $>$ 0.005 , then there is an effect of the free variable $(\mathrm{X})$ on the bound variable $(\mathrm{Y})$ or the hypothesis is rejected.

\section{FINDINGS AND DISCUSSION}

The questionnaire used in this case is a response from the integration of traditional games, the character of Peace Love and the patriotism of learners. The questionnaire generates a student response to the traditional game of Hide and seek that has been disseminated and processed can be seen in the table below:

Table 5. Student Response to hide and seek at Elementary School

\begin{tabular}{|c|c|c|c|c|c|c|c|c|c|c|}
\hline \multicolumn{11}{|l|}{ Category } \\
\hline \multirow[t]{2}{*}{ Interval } & \multirow[t]{2}{*}{ Attitude } & \multicolumn{2}{|c|}{ Gender } & \multirow[t]{2}{*}{ Total } & \multirow[t]{2}{*}{ "Mean } & \multirow[t]{2}{*}{ Min } & \multirow[t]{2}{*}{ Max } & \multirow[t]{2}{*}{ Median } & \multirow[t]{2}{*}{ Std.dev } & \multirow[t]{2}{*}{$\overline{\overline{\%}}$} \\
\hline & & $\mathbf{f}$ & $\mathbf{m}$ & & & & & & & \\
\hline $86-90$ & Very Bad & 1 & 1 & 2 & & & & & & 8,69 \\
\hline $91-95$ & $\mathrm{Bad}$ & 1 & & 1 & & & & & & 4,34 \\
\hline $96-100$ & Enough & 1 & 1 & 2 & 102,7 & 86 & 110 & 97,3 & 5,9 & 8.69 \\
\hline $101-105$ & Good & 4 & 6 & 10 & & & & & & 43,47 \\
\hline $106-110$ & Excellent & 4 & 4 & 8 & & & & & & 34,78 \\
\hline TOTAL & & 11 & 12 & 23 & & & & & 100 & \\
\hline
\end{tabular}


Table 6. Student Response to Traditiona in Madrasah Ibtidaiyah

\begin{tabular}{|c|c|c|c|c|c|c|c|c|c|c|}
\hline \multicolumn{11}{|l|}{ Category } \\
\hline \multirow[t]{2}{*}{ Interval } & \multirow[t]{2}{*}{ Attitude } & \multicolumn{2}{|c|}{ Gender } & \multirow[t]{2}{*}{ Total } & \multirow[t]{2}{*}{ Mean } & \multirow[t]{2}{*}{ Min } & \multirow[t]{2}{*}{ Max } & \multirow[t]{2}{*}{ Median } & \multirow[t]{2}{*}{ Std.dev } & \multirow[t]{2}{*}{$\%$} \\
\hline & & f & $\mathbf{m}$ & & & & & & & \\
\hline $86-90$ & Very Bad & 1 & 1 & 2 & & & & & & 9,52 \\
\hline $91-95$ & Bad & 1 & 1 & 2 & & & & & & 9,52 \\
\hline $96-100$ & Enough & 1 & 1 & 2 & 102,7 & 86 & 110 & 97,3 & 5,9 & 9,52 \\
\hline $101-105$ & Good & 2 & 3 & 5 & & & & & & 23,80 \\
\hline $106-110$ & Excellent & 6 & 4 & 10 & & & & & & 47,61 \\
\hline TOTAL & & 11 & 10 & 21 & & & & & 100 & \\
\hline
\end{tabular}

Table 7. Peace-Loving Character of Learners on Integrating Traditional Games of Hide and seek

\begin{tabular}{|c|c|c|c|c|c|c|c|c|c|c|}
\hline \multicolumn{7}{|l|}{ Category } & \multirow{3}{*}{ Max } & \multirow{3}{*}{ Median } & \multirow{3}{*}{ Std.dev } & \multirow{3}{*}{$\%$} \\
\hline \multirow[t]{2}{*}{ Interval } & \multirow[t]{2}{*}{ Attitude } & \multicolumn{2}{|c|}{ Gender } & \multirow[t]{2}{*}{ Total } & \multirow[t]{2}{*}{ "Mean } & \multirow[t]{2}{*}{ "Min } & & & & \\
\hline & & $\mathbf{f}$ & $\mathbf{m}$ & & & & & & & \\
\hline $39-46$ & Very Bad & 1 & 4 & 5 & & & & & & 11,36 \\
\hline $47-54$ & $\mathrm{Bad}$ & 3 & 4 & 7 & & & & & & 15,90 \\
\hline $55-62$ & Enough & 4 & 4 & 8 & 50,75 & 39 & 78 & 59,5 & 6,2 & 18,20 \\
\hline $63-70$ & Good & 5 & 8 & 13 & & & & & & 29,54 \\
\hline $71-78$ & Excellent & 6 & 5 & 11 & & & & & & 25,00 \\
\hline TOTAL & & 19 & 25 & 44 & & & & & 100 & \\
\hline
\end{tabular}

Table 8. Patriotism character at The Integration of Traditional Games Hide and seek

\begin{tabular}{|c|c|c|c|c|c|c|c|c|c|c|}
\hline \multicolumn{11}{|l|}{ Category } \\
\hline \multirow[t]{2}{*}{$\overline{\text { Interval }}$} & \multirow[t]{2}{*}{ Attitude } & \multicolumn{2}{|c|}{ Gender } & \multirow[t]{2}{*}{ Total } & \multirow[t]{2}{*}{ Mean } & \multirow[t]{2}{*}{ Min } & \multirow[t]{2}{*}{ Max } & \multirow[t]{2}{*}{ "Median } & \multirow[t]{2}{*}{ Std.dev } & \multirow[t]{2}{*}{ \% } \\
\hline & & $\mathbf{f}$ & $\mathbf{m}$ & & & & & & & \\
\hline $55-57$ & Very Bad & 2 & 1 & 3 & \multirow{5}{*}{64,2} & \multirow{5}{*}{55} & \multirow{5}{*}{70} & \multirow{5}{*}{64,7} & \multirow{5}{*}{3,3} & 6,81 \\
\hline $58-60$ & $\mathrm{Bad}$ & 5 & 2 & 7 & & & & & & 15,90 \\
\hline $61-63$ & Enough & 6 & 5 & 11 & & & & & & 25,00 \\
\hline $64-66$ & Good & 8 & 6 & 14 & & & & & & 31,81 \\
\hline $67-71$ & Excellent & 5 & 4 & 9 & & & & & & 20,45 \\
\hline TOTAL & & 26 & 18 & 44 & & & & & 100 & \\
\hline
\end{tabular}

From the table above, the significant values resulting from the normality test can be seen. It is based on Kolmogrof-Smirnof from two independent samples. From the table above sig $>0.05$. The normality value of 0.209 at the sig value of normality means that the existing data is normal, because the sig>0.05 value. The following is also done linearity test on the data as in the table below: 


\section{Normality and Linearity Test}

Here are the results of the assumption of normality and linearity tests on the data response to the character of peace love and loving character of the student's homeland using SPSS 20, which can be seen in the table below:

\section{Table 9. The Normality test}

\section{One-Sample Kolmogorov-Smirnov Test}

\begin{tabular}{llr}
\hline \multicolumn{2}{c}{ Unstandardized Residual } \\
\hline $\mathrm{N}$ & Mean & 44 \\
Normal Parameters ${ }^{\mathrm{a}, \mathrm{b}}$ & Std. Deviation & $\mathrm{oE}-7$ \\
& Absolute & 3.00375752 \\
& Positive & .124 \\
Most Extreme & Negative & .084 \\
Differences & & -.124 \\
Kolmogorov-Smirnov Z & & .825 \\
Asymp. Sig. (2-tailed) & & .504 \\
\hline
\end{tabular}

a. Test distribution is Normal.

b. Calculated from data.

From the table above, the significant values resulting from the normality test can be seen. It is based on Kolmogrof-Smirnof from two independent samples. From the table above sig>0.05. The normality value of 0.504 at the sig normality value means that the existing data is normal, because the sig>0.05 value. The following is also done linearity test on the data as in the table below:

Table 10. Linearity test of loving peace

\begin{tabular}{|c|c|c|c|c|c|c|c|}
\hline \multicolumn{8}{|c|}{ ANOVA Table } \\
\hline \multirow[b]{4}{*}{$\begin{array}{l}\text { RESPON * CINTA } \\
\text { DAMAI }\end{array}$} & \multirow{4}{*}{$\begin{array}{l}\text { Between } \\
\text { Groups }\end{array}$} & \multirow[b]{2}{*}{ (Combined) } & \multirow{2}{*}{$\begin{array}{r}\begin{array}{l}\text { Sum of } \\
\text { Squares }\end{array} \\
401.141\end{array}$} & \multirow{2}{*}{$\begin{aligned} \mathrm{df} \\
8\end{aligned}$} & \multirow{2}{*}{$\begin{array}{l}\begin{array}{c}\text { Mean } \\
\text { Square }\end{array} \\
50.143\end{array}$} & \multirow{2}{*}{$\begin{array}{c}\mathrm{F} \\
1.542\end{array}$} & \multirow{2}{*}{$\begin{array}{l}\text { Sig. } \\
.178\end{array}$} \\
\hline & & & & & & & \\
\hline & & Linearity & 105.926 & 1 & 105.926 & 3.258 & .080 \\
\hline & & $\begin{array}{l}\text { Deviation from } \\
\text { Linearity }\end{array}$ & 295.215 & 7 & 42.174 & 1.297 & .280 \\
\hline & \multicolumn{2}{|l|}{ Within Groups } & 1137.836 & 35 & 32.510 & & \\
\hline & \multicolumn{2}{|l|}{ Total } & 1538.977 & 43 & & & \\
\hline
\end{tabular}


From the table above, the sign value generated from the linearity test of the data above the value sig $>0.05$ then the data is said to be linear, the linearity value of sig $>0.280$ means that the existing data is linear, because the value sig $>0.05$.

Table 11. Linearity test of patriotism

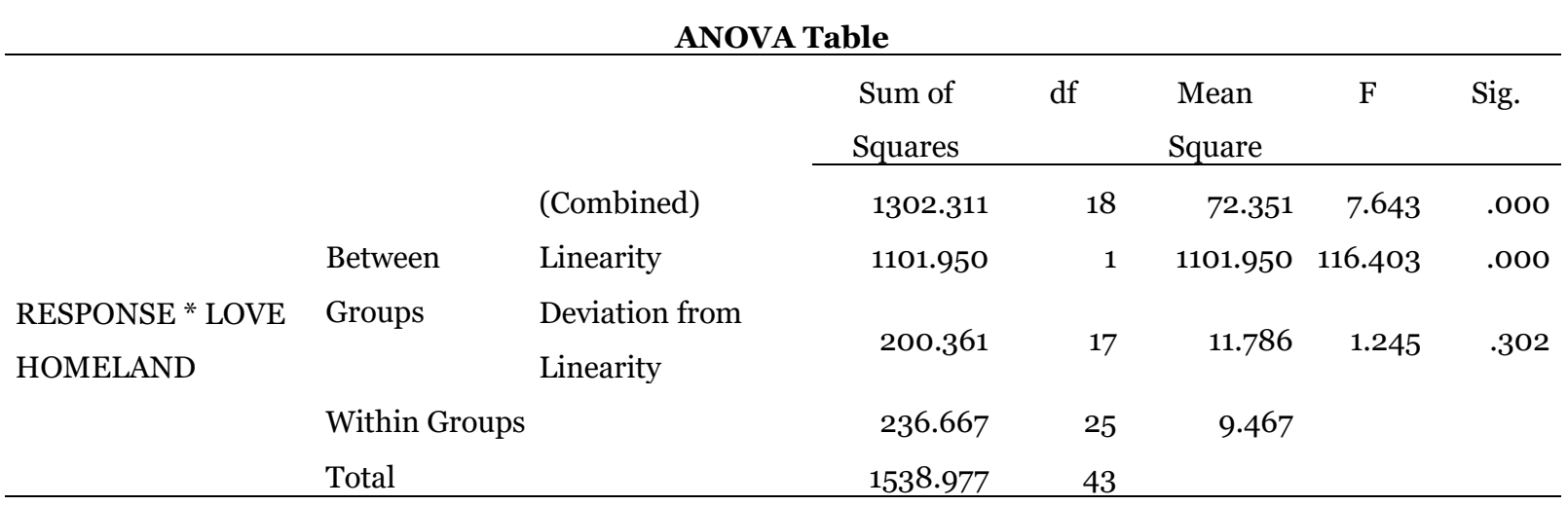

From the table above can be seen the significant values resulting from the linearity test. From the data above the value sig $>0.05$ then the data is said to be linear. The linearity value of 0.302 means that the existing data is linear, because the sig value $>0.05$.

\section{Regression Test in State Elementary Schools}

Here is a table of results from the data obtained on the integration of traditional games of Hide and seek to the response of students, peace-loving characters and love characters of the homeland:

Table 12. Regression Test at elementary school

\begin{tabular}{lllllll}
\hline \multicolumn{7}{c}{ ANOVA $^{\text {a }}$} \\
\hline Type & & Sum of Squares & Df & Mean Square & F & Sig. \\
& Regression & 28.777 & 2 & 14.388 & 1.287 & .0oo $^{\text {b }}$ \\
1 & Residual & 458.201 & 41 & 11.176 & & \\
& Total & 486.977 & 43 & & & \\
\hline
\end{tabular}

a. Dependent Variable: Response

b. Predictors: (Constant), Love of the Fatherland, Love of Peace

The ANOVA table above is used to see the presence or absence of simultaneous influence between two vaiabel $\mathrm{X}$ against $\mathrm{Y}$. Based on the table above, a significant value of o.oo where the value sig<0.05. From the existing sig values in accordance with the decision-making results, the existing hypothesis is accepted, namely there is an influence on the variety of $\mathrm{X} 1$ and $\mathrm{X} 2$ simultaneously on variable Y.

Table 13. Percentage of Regression Tests in Elementary School

\begin{tabular}{lcccc}
\hline \hline \multicolumn{4}{c}{ Model Summary } \\
\hline \hline Model & $\mathrm{R}$ & R Square & $\begin{array}{c}\text { Adjusted R } \\
\text { Square }\end{array}$ & $\begin{array}{c}\text { Std. Error of the } \\
\text { Estimate }\end{array}$ \\
\hline 1 & & .559 & .013 & 3.34300 \\
a. & $\begin{array}{l}.643^{\mathrm{a}} \\
\end{array}$ & Predictors: (Constant), love homeland, peace love & \\
\hline \hline
\end{tabular}


The results of the table above are tables to find out the percentage of contribution of influence on variables $\mathrm{X} 1$ and $\mathrm{X} 2$ to variable $\mathrm{Y}$. In the table above is known the value of R Square of 0.559 . This means that the effect of variables $\mathrm{X} 1$ and $\mathrm{X} 2$ simultaneously on variable $\mathrm{Y}$ is $55.9 \%$.

Table 14. Regression Test Equation in Elementary School

\begin{tabular}{|c|c|c|c|c|c|c|}
\hline \multicolumn{7}{|c|}{ Coefficients $^{\mathbf{a}}$} \\
\hline \multirow{2}{*}{\multicolumn{2}{|c|}{ Model }} & \multicolumn{2}{|c|}{ Unstandardized Coefficients } & \multirow{2}{*}{$\begin{array}{c}\text { Standardized } \\
\text { Coefficients } \\
\text { Beta } \\
\end{array}$} & \multirow[t]{2}{*}{$\mathrm{t}$} & \multirow[t]{2}{*}{ Sig. } \\
\hline & & B & Std. Error & & & \\
\hline & (Constant) & 61.875 & 9.672 & & 6.397 & .000 \\
\hline \multirow[t]{2}{*}{1} & LovePeace & -.042 & .085 & -.074 & -.490 & .000 \\
\hline & Lovehomeland & .126 & .082 & .233 & 1.535 & .000 \\
\hline
\end{tabular}

a. Dependent Variable: Response

regression equation

From these results it can be known that the character of Peace Love has a t count of 1,903 with a significant for Peace Love character of 0.00 smaller than the significant level of 0.05. Then the first hypothesis is accepted so that it can be concluded that partially the character of Peace Love affects the response of learners to the integration of traditional games of Hide and seek. The variable character of the love of the homeland has a calculated value of 0.755 while with a significant for the character variable of the country's love of 0.00 is smaller than the significant level of 0.05. Then the hypothesis is accepted so that it can be concluded that partially the character of the love of the homeland affects learners' response. Based on the double regression test table above, the two regression equations are obtained as follows:

$$
\mathbf{Y}=61,875+0.042 \mathrm{X1}+\mathbf{0 . 1 2 6} \mathrm{X2}+\varepsilon
$$

\section{Regression Test in Madrasah Ibtidaiyah Negeri}

The results of the data obtained on the integration of traditional games of Hide and seekto the response of students, peace-loving characters and love characters of the homeland in the madrasah ibtidaiyah country as me:

Table 15. Regression Test in Madrasah Ibtidaiyah

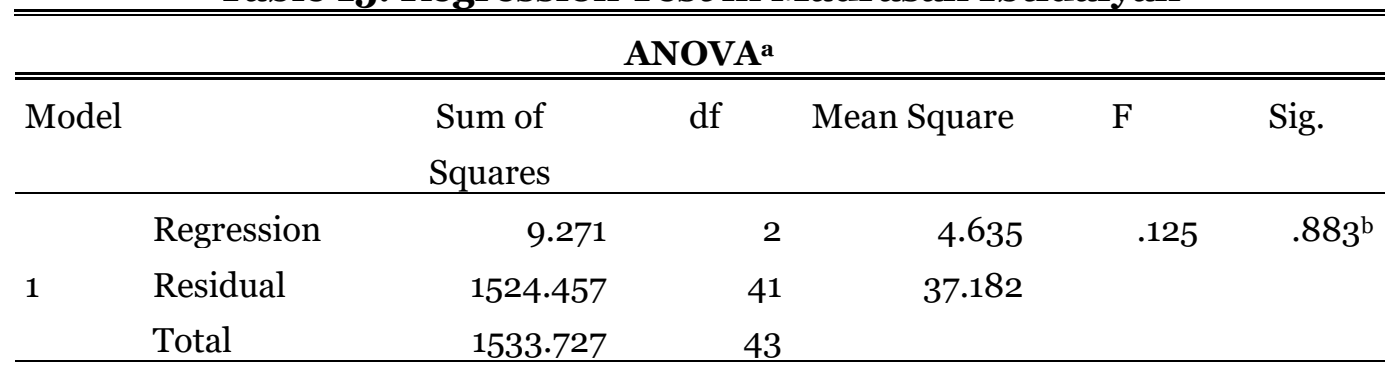

a. Dependent Variable: Response

b. Predictors: (Constant), lovehomeland, lovepeace 
The ANOVA table above is used to see whether there is a simultaneous influence between two vaiabel $\mathrm{X}$ against $\mathrm{Y}$. Based on the table above, a significant value of 0.042 where the value sig<0.05. From the existing sig values in accordance with the decision-making results, the existing hypothesis is accepted, namely there is an influence on the variety of $\mathrm{X} 1$ and $\mathrm{X} 2$ simultaneously on variable $\mathrm{Y}$.

Table 16. Percentage of Regression Tests in Madrasah Ibtidaiyah

\begin{tabular}{llccc}
\hline \hline \multicolumn{4}{c}{ Model Summary } \\
\hline Model & R & R Square & $\begin{array}{c}\text { Adjusted R } \\
\text { Square }\end{array}$ & $\begin{array}{c}\text { Std. Error of the } \\
\text { Estimate }\end{array}$ \\
\cline { 3 - 4 } 1 & & \multicolumn{2}{c}{-.742} & 6.09769 \\
\cline { 3 - 4 } & & $.678^{\mathrm{a}}$ & .666 & \multicolumn{3}{c}{} \\
\hline \multicolumn{2}{l}{ a. Predictors: (Constant), lovehomeland, lovepeace } \\
\hline \hline
\end{tabular}

The table above results are tables to determine the percentage of influence contributions on variables $\mathrm{X} 1$ and $\mathrm{X} 2$ to variables $\mathrm{Y}$. In the table above is known the value of $\mathrm{R}$ Square of 0.666. This means that the simultaneous effect of variables $\mathrm{X} 1$ and $\mathrm{X} 2$ on variable $\mathrm{Y}$ is $66.6 \%$.

Table 17. Regression Test Equation in Madrasah Ibtidaiyah

\begin{tabular}{|c|c|c|c|c|c|c|}
\hline \multicolumn{7}{|c|}{ Coefficients ${ }^{\mathbf{a}}$} \\
\hline \multirow{3}{*}{\multicolumn{2}{|c|}{ Model }} & \multirow{2}{*}{\multicolumn{2}{|c|}{ Unstandardized Coefficients }} & Standardized & \multirow[t]{3}{*}{$\mathrm{t}$} & \multirow[t]{3}{*}{ Sig. } \\
\hline & & & & Coefficients & & \\
\hline & & $\mathrm{B}$ & Std. Error & Beta & & \\
\hline \multirow{3}{*}{1} & (Constant) & 110.073 & 18.067 & & 6.092 & .000 \\
\hline & Peace love & .032 & .154 & .033 & .206 & .838 \\
\hline & Love homeland & -.139 & .284 & -.078 & -.490 & .627 \\
\hline
\end{tabular}

a. Dependent Variable: Response

From these results it can be known that the character of Peace love has a count of 1,260 with a significance for The Peace Love character of 0.00 smaller than the significant level of 0.05. Then the first hypothesis is accepted so that it can be concluded that partially the character of Peace Love affects learners' response to the integration of traditional games of Hide and seek. The variable character of the love of the homeland has a calculated value of 6,092a significant amount for the variable character of the country's love ofo.28 greater than the significant level of 0.05. Then the second hypothesis is rejected so that it can be concluded that partially the character of love of the homeland has no effect on the response of learners. Based on the double regression test table above, the two regression equations are obtained as follows:

$$
\mathbf{Y}=\mathbf{1 1 0}, 073+0.032 \mathrm{X1}+\mathbf{0 . 1 3 9} \mathrm{X2}+\varepsilon
$$

In addition to quantitative data obtained, supporting data in this study is qualitative data obtained from the results of interviews conducted with students and teachers. The interview results were conducted on students to find out the response, the character of Peace Love and the character of patriotism at the time of the integration of traditional games of Hide and seek, Questions in interviews to measure qualitative data on research. At the time of integrating traditional games in learning, students feel happy and excited in learning, because of learning while playing. Students are more active not in the cognitive realm alone but in their affective 
and psychomotor realms. The results of interviews on learners can be known still rarely do teachers provide learning with the integration of traditional games such as Hide and seek. Furthermore, the results of the interview were conducted to the teacher as an educator to find out the knowledge and ability of the teacher in the integration of traditional games of Hide and seek. Teachers still do not integrate games into learning. Games are introduced to students only on sports learning. The rest is only theoretical learning only. Teachers rarely introduce traditional games to students in the classroom. According to him, integrating traditional games can be a new alternative for an educator in introducing a hereditary culture, especially in traditional games integrated because many good values can be applied to learners.

The integration of traditional Hide and seek on learning games in class IV of Sridadi State Elementary School and Madrasah Ibtidaiyah 1 Batang Hari was given a response questionnaire to see the student's response. With results obtained in the good category, 43.47\% with 10 of the 23 students in Sridadi State Elementary School 55 / I and at Madrasah Ibtidaiyah 1 Batang 47.61\% with 10 of 21 students. Both responses in each school belong to the good category, and this is because the integration of traditional games students are more active in learning, not only have cognitive abilities, but students will also have affective and psychomotor abilities. The integration of traditional games is considered very appropriate to the character and age of elementary school children.

In addition to the character of Peace Love, the character of love of the homeland is also a hugger to measure the magnitude of the character of the love of the homeland of learners in learning. The character of the love of the homeland is students' attitude to appreciate the homeland as evidenced by Loving Local Works and preserving the existing culture(Fauzan, \& Nashar, 2017; Oktavianti, I., \& Ratnasari, 2018; Nahak, 2019). This study obtained results with a good category of $31.81 \%$ with 14 out of 44 students. This shows learners have a love character of the country who likes to play and love traditional games of Hide and seek which is a game originating from Indonesia.

Data from the assumption test analysis shows that the resulting data is normal and linear, judging from data that shows significant value. The normality and linearity test in a study used two independent samples(Widhiarso, 2012; Saregar, Latifah \& Sari, 2016; Sukestiyarno \& Agoestanto, 2017). With the following testing criteria: If the Sig > value is 0.05 then the variance is normal, while if the sig<0.05 value, the variance is not normal. From the table above it can be known that the value is 0.209 so that the data obtained can be said to be normal, because the value sig>0.05. While in the linearity test, it can be known that the value of 0.280 on linear measurements of the student's response and the character of Peace Love and 0.302 on the response and character of the love of the homeland and the data obtained can be said to be linear, because the value sig>0.05. Normality tests and linearity tests become very important to be fulfilled because in the initial assumption of a linear regression equation, it is said to be good if the regression error is normal and linear distribution (Haryono \& Wardoyo, 2012; Sutopo \& Slamet, 2017; Ningsih \& Suniasih, 2020).

While the hypothesis test is seen from the regression test table is done to see the proposed hypothesis is acceptable or not. Regression tests are carried out on the response, the character of Peace Love, and the love of the student's homeland. The regression test conducted resulted from the spread of the questionnaire to two different schools, namely State Elementary School 55/I Sridadi and Madrasah Ibtidaiyah 1 Batang Hari. In the analysis of regression tests that have 
been done the proposed hypothesis is well received can be seen in the existing table that the sig value is less than 0.05. In Sridadi State Elementary School, results are significant values of o.00 where sig<0.05. From the existing sig values by the decision-making results, the existing hypothesis is accepted, namely there is an influence on the variety of X1 and X2 simultaneously on variable Y. With the percentage contribution of influence on the value of R Square of 55.9\% with the following multiple regression equations: $\mathrm{Y}=\mathrm{Y}=61,875+0.042 \mathrm{X} 1+0.126 \mathrm{X} 2+\varepsilon$

Regression tests were also conducted in Madrasah Ibtidaiyah Negeri 1 Batang Hari with a significant value of 0.02 where the sig<0.05 value. Thus the existing hypothesis is accepted, namely there is an influence on the variety of X1 and X2 simultaneously on variable $\mathrm{Y}$. With the percentage of influence contribution on the value of $\mathrm{R}$ Square of $66.6 \%$ obtained the following multiple regression equations: $\mathrm{Y}=110,073+0.032 \mathrm{X} 1+0.284 \mathrm{X} 2+\varepsilon$

The findings of this research is in line with previous research conducted by (Andriani, 2012; Kawuryan,2016; Praheto \& Sayekti, 2021) researched by integrating traditional games on learning. According to each researcher, traditional games have a huge influence on the mental, physical, and mental development of children. Traditional games can also be to develop the value of a child's character. In each study integrates character values through traditional games in elementary school learning. While in this study was carried out the integration of traditional games on learning seen from the response, the character of Peace Love and the character of the love of the homeland of learners in The State Elementary School and Madrasah Ibtidaiyah Negeri. Where in the integration of traditional games, the response given by students to research in the category is good when viewed from the results of existing questionnaires.

\section{CONCLUSION}

Traditional games like Hide and Seek were found to have an impact on children's responses, as well as their character traits like Peace Love and patriotism character, in both elementary schools and Madrasah Ibtidaiyah. According to the study results, the integration of traditional games of Hide and seek on learning was found to be the most effective. A regression test has found that the character of Peace and Love and patriotism have a significant impact on the students' responses. The sig is less than 0.05 in both variables $\mathrm{X}$ with the results of regression equations on the integration of traditional hide-and-seek games of $\mathrm{Y}$ when using regression equations. When it comes to Hide and Seek in Madrasah Ibtidaiyah, two variables are used: the character of peace love and the character of patriotism. The response is used as a variable Y. The hypothesis is rejected when the sig obtained for variable X1 is less than 0.05, but the sig obtained for variable $\mathrm{X} 2$ is greater than 0.05 , as shown by the regression equations. As a result, incorporating traditional games into the learning process can serve as an engaging and age-appropriate alternative to more traditional teaching methods. Students are more engaged in learning with the game, making it easier for teachers to introduce hereditary culture. This is based on information gleaned from teacher and student interviews about the inclusion of classic hide-and-seek games.

\section{REFERENCES}

Arthur, J. (2014). Traditional approaches to character education in Britain and America. In Handbook of Moral and Character Education. https://doi.org/10.4324/9780203114896

Andriani, T. (2012). Permainan tradisional dalam membentuk karakter anak usia dini. Sosial Budaya, 9(1), 121-136. 
Agoestanto, A., \& Sukestiyarno, Y. L. (2017, March). Analysis of mathematics critical thinking students in junior high school based on cognitive style. In Journal of Physics: Conference Series (Vol. 824, No. 1, p. 012052). IOP Publishing.

bsnp 2007. (2017). Wawancara terstruktur dilakukan ketika peneliti sudah menyediakan pertanyaan-pertanyaan kepada sumber informasi yang tersusun secara sistematis. Sedangkan wawancara tidak terstruktur dilakukan secara bebas tanpa menggunakan pedoman wawancara yang tersusun. STILISTIKA: Jurnal Bahasa, Sastra, Dan Pengajarannya, 2(1), 226-239.

Berlian, Z. (2018). Competency Analysis of Job Satisfaction and Organizational Commitment to Lecturers Who Teach at Private Universities in the Area of Southern Sumatra. American Research Journal of Business and Management, 4(1), 1-6.

Damon, W. (2003). Bringing in a new era in character education. In Choice Reviews Online (Vol. 41, Issue 03). https://doi.org/10.5860/choice.41-1684

Dharma, K., Cepi, T., \& Permana Johar. (2017). PENDIDIKAN KARAKTER.pdf.

Etikan, I. (2016). Comparison of Convenience Sampling and Purposive Sampling. American Journal of Theoretical and Applied Statistics, 5(1), 1. https://doi.org/10.11648/j.ajtas.20160501.11

El Zein, A., Shelnutt, K. P., Colby, S., Vilaro, M. J., Zhou, W., Greene, G., ... \& Mathews, A. E. (2019). Prevalence and correlates of food insecurity among US college students: a multiinstitutional study. BMC public health, 19(1), 1-12.

Fajarini, U. (2014). Peranan Kearifan Lokal Dalam Pendidikan Karakter. SOSIO DIDAKTIKA: Social Science Education Journal, 1(2). https://doi.org/10.15408/sd.vii2.1225

Fauzan, R., \& Nashar, N. (2017). "Mempertahankan Tradisi, Melestarikan Budaya" (Kajian Historis dan Nilai Budaya Lokal Kesenian Terebang Gede di Kota Serang). Jurnal $\begin{array}{llll}\text { Candrasangkala Pendidikan } & \text { Sejarah, } & 3(1), & 1 .\end{array}$ https://doi.org/10.30870/candrasangkala.v3i1.2882

Fenn-Berrabaß, C. (2001). Öffnen - Verwendung von PEEL-Folien. VDI Berichte, 1589, 105-112.

Guru, P., Anak, P., Dini, U., Makassar, U. I., City, M., \& Makassar, K. (2021). PENINGKATAN MOTORIK KASAR ANAK MELALUI PERMAINAN TRADISIONAL HIDE AND SEEK DI TAMAN KANAK-KANAK. 7(April).

Gunawan, G., Harjono, A., Hermansyah, H., \& Herayanti, L. (2019). GUIDED INQUIRY MODEL THROUGH VIRTUAL LABORATORY TO ENHANCE STUDENTS'SCIENCE PROCESS SKILLS ON HEAT CONCEPT. Jurnal Cakrawala Pendidikan, 38(2), 259-268.

Hasanah, H. (2017). Teknik-teknik observasi (sebuah alternatif metode pengumpulan data kualitatif ilmu-ilmu sosial). At-Taqaddum, 8(1), 21-46.

Haryono, S., \& Wardoyo, P. (2012). Structural equation modeling. Bekasi: PT Intermedia Personalia Utama.

Hery Yuli Setiawan, M. (2016). Improving Early Childhood Social Skills Through Traditional Games. Jurnal Dimensi Pendidikan Dan Pembelajaran, 5(2), 1-8.

Lastasabuju, M., \& Habaridota, B. (2018). JP2D ( Jurnal Penelitian Pendidikan Dasar ) UNTAN JP2D ( Jurnal Penelitian Pendidikan Dasar ) UNTAN. JP2D (Jurnal Penelitian Pendidikan Dasar) UNTAN, 1(3), 110-119.

Kawuryan, S. P. (2016). PENGEMBANGAN MODEL PEMBELAJARAN TEMATIK BERBASIS PERMAINAN TRADISIONAL DAN BERORIENTASI PENDEKATAN SAINTIFIK. Jurnal Pedagogik Pendidikan Dasar, 4(1), 87-101.

Lehtinen, E., Hakkarainen, K., \& Palonen, T. (2014). Understanding Learning for the Professions: How Theories of Learning Explain Coping with Rapid Change. 199-224. https://doi.org/10.1007/978-94-017-8902-8_8

Maryuliana, M., Subroto, I. M. I., \& Haviana, S. F. C. (2016). Sistem informasi questionnaire pengukuran skala kebutuhan materi pembelajaran tambahan sebagai pendukung 
pengambilan keputusan di sekolah menengah atas menggunakan skala likert. TRANSISTOR Elektro dan Informatika, 1(1), 1-12.

Ma `arif, M. A., \& Rofiq, M. H. (2018). The Role of Islamic Education Teachers in Improving the Character of Nationalism in Boarding School. EDUKASI: Jurnal Pendidikan Islam, 6(1), 064-078. http://ejournal.staim-tulungagung.ac.id/index.php/EDUKASI/article/view/323

Miskawati, M. (2019). Upaya Meningkatkan Kreativitas Anak Dalam Pembelajaran Seni Tari Melalui Strategi Belajar Sambil Bermain di TK Islam Sa'adatul Khidmah Tahun Pelajaran 2016/2017. Jurnal Ilmiah Dikdaya, 9(1), 45. https://doi.org/10.33087/dikdaya.v9i1.123

Moh. Toriqul Chaer. (2016). Islam dan Pendidikan Cinta Damai. Istawa: Jurnal Pendidikan Islam, 2(1), 73-94.

Muhali, M. (2019). Pembelajaran Inovatif Abad Ke-21. Jurnal Penelitian Dan Pengkajian Ilmu Pendidikan: E-Saintika, 3(2), 25. https://doi.org/10.36312/e-saintika.v3i2.126

Mulvey, C. (1984). Wage Policy and Wage Determination in 1983. Journal of Industrial Relations, 26(1), 112-119. https://doi.org/10.1177/002218568402600108

Munawwaroh, A. (2019). Keteladanan Sebagai Metode Pendidikan Karakter. Jurnal Penelitian Pendidikan Islam, 7(2), 141. https://doi.org/10.36667/jppi.v7i2.363

Murniyetti, M., Engkizar, E., \& Anwar, F. (2016). Pola Pelaksanaan Pendidikan Karakter Terhadap Siswa Sekolah Dasar. Jurnal Pendidikan Karakter, 6(2), 156-166. https://doi.org/10.21831/jpk.v6i2.12045

Nahak, H. M. (2019). Upaya melestarikan budaya indonesia di era globalisasi. Jurnal Sosiologi Nusantara, 5(1), 65-76.

Ningsih, N. L. P. Y. W., \& Suniasih, N. W. (2020). Kesiapan Belajar dan Aktualisasi Diri Meningkatkan Hasil Belajar IPA. Mimbar Ilmu, 25(3), 367-379.

Ohler, C. (2002). Artikel 4 (pp. 369-371). https://doi.org/10.1007/978-3-642-56129-0_13

Oktavianti, I., \& Ratnasari, Y. (2018). Etnopedagogi Dalam Pembelajaran Di Sekolah Dasar Melalui Media Berbasis Kearifan Lokal. Refleksi Edukatika : Jurnal Ilmiah Kependidikan, 8(2). https://doi.org/10.24176/re.v8i2.2353

Paulsen, T. R., Colville, L., Kranner, I., Daws, M. I., Högstedt, G., Vandvik, V., \& Thompson, K. (2013). Physical dormancy in seeds: A game of hide and seek? New Phytologist, 198(2), 496-503. https://doi.org/10.1111/nph.12191

Praheto, B. E. (2017). Metode 2M2PR Berbasis Quantum Learning dan Permainan Tradisional dalam Pembelajaran Bahasa Indonesia di Sekolah Dasar. Jurnal Pendidikan Ke-SD-An, 4(1), 278-283.

Purnamasari, H., \& Sartinah, E. P. (2019). Permainan Tradisional Hide and seek Modifikasi Terhadap Keterampilan Sosial Siswa Tunagrahita Ringan. Jurnal Pendidikan Khusus, 116.

Putri, R. D. P., \& Safitri, N. E. (2018). Implementasi Nilai-Nilai Karakter KECE (Komunikatif, Empatik, Cinta Damai, Energik) di Sekolah Dasar Dalam Pemanfaatan Bonus Demografi. In Prosiding Seminar Nasional Pendidikan Fisika "Motogpe."

Rijali, A. (2019). Analisis data kualitatif. Alhadharah: Jurnal Ilmu Dakwah, 17(33), 81-95

Rohmawati, A. (2015). Efektivitas Pembelajaran. Jurnal Pendidikan Usia Dini, 9(1), 15-32.

Rofiah, E., Aminah, N. S., \& Ekawati, E. Y. (2013). Penyusunan Instrumen tes kemampuan berpikir tingkat tinggi fisika pada siswa SMP. Jurnal pendidikan fisika, 1(2).

rosalia, rosalia, \& Mas'udah, M. (2015). Pengaruh Permainan Hide and seek Terhadap Kemampuan Sosial Emosional Anak. PAUD Teratai, 4(2).

Salleh, M. S. (2014). International Journal of Education and Research. In Organizational and Definitional Reconfiguration of Zakat Management (Vol. 2, Issue 5, pp. 61-70).

Sari, N., \& Wardani, R. (2015). Pengolahan dan Analisis Data Statistika dengan SPSS. Deepublish. 
Saregar, A., Latifah, S., \& Sari, M. (2016). Efektivitas model pembelajaran cups: dampak terhadap kemampuan berpikir tingkat tinggi peserta didik Madrasah Aliyah Mathla'Ul Anwar Gisting Lampung. Jurnal Ilmiah Pendidikan Fisika Al-Biruni, 5(2), 233-244.

Schwendimann, B. A., Rodríguez-Triana, M. J., Vozniuk, A., Prieto, L. P., Boroujeni, M. S., Holzer, A., Gillet, D., \& Dillenbourg, P. (2016). Understanding learning at a glance. 532533. https://doi.org/10.1145/2883851.2883930

Setyoningsih, Y. D. (2019). Konseling Kelompok dengan Teknik Psikodrama "Nilai Karakter Cinta Damai" untuk Mereduksi Perilaku Agresif Siswa. Journal Empathy Couns, 1(1), 3243 .

Sudibyo, E., Jatmiko, B., \& Widodo, W. (2017). Pengembangan instrumen motivasi belajar fisika: questionnaire. Jurnal Penelitian Pendidikan IPA, 1(1), 13-21.

Supriyanto, A. \& W. A. (2017). Operasional Aspek Kedamaian , Menghargai. Jurnal Ilmiah Counsellia, 1, 61-70.

Sutopo, E. Y., \& Slamet, A. (2017). Statistik Inferensial. Penerbit Andi.

Syaefudin, S., \& Santoso, S. (2018). Tipologi Kepemimpinan Kepala Sekolah dalam Pembentukan Karakter Cinta Damai Siswa SMP Piri 1 Yogyakarta. MANAGERIA: Jurnal Manajemen Pendidikan Islam, 3(1), 47-67. https://doi.org/10.14421/manageria.2018.31o3

Talapessy, R., Kumalasari, D., \& Salouw, J. H. (2020). Urgency of character building of students' love of homeland through the historical teacher' $s$ role in state senior high school 4 of Kairatu, Ambon. ScienceRise: Pedagogical Education, o(6 (39)), 26-30. https://doi.org/10.15587/2519-4984.2020.218066

Widhiarso, W. (2012). Tanya Jawab tentang Uji Normalitas. Fakultas Psikologi UGM, 1-5.

Widiana, I. W. (2016). Pengembangan asesmen proyek dalam pembelajaran ipa di sekolah dasar. JPI (Jurnal Pendidikan Indonesia), 5(2), 147-157.

Widiatmaka, P. (2016). Pembangunan Karakter Nasionalisme Peserta Didik Di Sekolah Berbasis Agama Islam. JPK (Jurnal Pancasila Dan Kewarganegaraan), 1(1), 25-33. http://journal.umpo.ac.id/index.php/JPK/article/view/301

Wipulanusat, W., Panuwatwanich, K., Stewart, R. A., Arnold, S. L., \& Wang, J. (2020). Bayesian network revealing pathways to workplace innovation and career satisfaction in the public service. Journal of Management Analytics, 7(2), 253-280. 
Al- Ishlah: Jurnal Pendidikan, December 2021, 13 (3), Pages 2651-2666

Asrial, Syahrial, Dwi Agus Kurniawan, Muhammad Dewa Zulkhi

This page is intentionally left blank 